\title{
Class, Citizenship and Regeneration: Glasgow and the Commonwealth Games 2014
}

\section{ABSTRACT}

Through a focus on 'consumer-citizenship' this paper seeks to highlight the class practices inherent in urban regeneration. Using Glasgow's 2014 Commonwealth Games (CWGs) as an illustrative example, it seeks to underline the market-led processes that underpin state interventions to transform 'problem people, and problem places' (Damer 1989) into sites of 'active' consumption and 'responsible' citizenship. In doing so, we synthesise conceptual insights from the Marxist-influenced gentrification literature and the Foucauldian-inspired housing renewal literature. We forward this to initiate further academic debate and empirical enquiry on the specific issue of mega sporting events 2014 CWGs.

Keywords: urban regeneration, class, citizenship, consumption, Glasgow, Commonwealth Games

\section{INTRODUCTION}

Mega sporting events are big business. The capacity of such events to regenerate cities is clearly evident in the UK with the forthcoming and much celebrated 2012 Olympics in London and 2014 CWGs in Glasgow. Yet there are limited coherent theoretical approaches and critiques and sustained empirical inquiries in this subject area. Through a focus on 'consumer-citizenship', this paper seeks to highlight the class practices inherent in urban regeneration. Using Glasgow's Commonwealth Games (CWGs) 2014 as an illustrative example, it underlines the market-led processes that underpin state interventions to transform 'problem people', and 'problem places' (Damer 1989; Mooney, 2008) into sites of 'active' consumption and 'responsible' citizenship. Urban regeneration here is understood as part and parcel of what Cochrane (2007) has described as 'active social policy'. In this regard, regeneration across the devolved UK is entangled with other aspects of policy making, not least with the remodelling and remaking of older forms of social welfarism, 
including the privatisation of public housing, welfare to work and other work activation programmes and, importantly, with criminal justice policy making, including concerns with disorder and 'anti-social behaviour'. In all of this these is a concerted attempt to make seemingly 'unproductive' people and places 'productive'. Different policy making sites come together with a shared concern to address the problems posed by particular populations, which are variously delineated by worklessness and their participation in behaviours alternatively considered as unruly or disorderly in some form; they are seen as being pathologically 'problematic' (Damer 1989). Working-class lives, particularly those of the most disadvantaged sections of the working-class, are deemed to be deficient or lacking and flawed in multiple ways which work to compound each other. This obfuscates the structural processes that have created inequality within these communities, which are often beyond the scope of local market-led interventions, such as state-led gentrification and housing renewal, to address. These interventions, commonly implemented as strategies of regeneration, actually contribute to the pathologisation of particular places and people by focusing on cultural 'failings' (Bauder 2002), and are also of questionable utility during a recession when labour market opportunities are considerably more constrained. Yet existing literature and explanations of gentrification and housing renewal remain disparate. Traditional gentrification literature struggles to fully explain its use in regeneration or how it relates to participation and citizenship, whilst literature on housing renewal tends to focus on issues of empowerment, moral responsibilisation, and is underpinned by Foucauldian interpretations. Whilst these literatures have points of connection, they often talk across each other and do not synthesise the pathologisation of problem populations and the classed practices involved in the neoliberalisation of social welfare.

We believe these debates can be brought together in a regeneration context, through a focus on consumption. Taking Bauman's (1998) idea of the 'flawed consumer', this paper argues that forms of consumption which do not correspond to the ideal consumer-citizen 
model are the target of policies of regeneration. Regeneration is used as a mode of restructuring traditional social welfare practices that are seen as deeply flawed and problematic in the new era of 'consumer-citizenship' wherein individualised consumption, choice and responsibility are regarded as paramount. The concept of consumer-citizenship often deployed in this literature effectively captures but does not get to the heart of class and material relations. In this paper we argue that these discrete regeneration strategies are inextricably linked and part of a wider discourse of neo-liberalisation, which is inherently class based, and can effectively be brought together to create a more sophisticated explanation. These processes, housing renewal, gentrification, sporting events etc., coalesce round the same goal: creating the more active consumer citizen in a moral and economic sense (Mclntyre and McKee 2008, 2009; McKee, In Press; Paton 2009, 2010). Consumer-citizenship paradoxically extends participation to citizens but, because this is based on consumption and ergo people's material propensity to consume, it simultaneously denies participation and disadvantages those who cannot afford to consume. Thus it compounds class inequality. Gentrification and tenure-mix can be seen as two particularly potent and inextricably linked strategies in this context but here we wish to highlight another area of urban regeneration: large-scale 'flagship' events. City elites compete for large scale events: Olympic Games, CWGs, Cities of Culture, Architecture, Music, Film and so on. This interpretation can be usefully applied to understand the policy focus on mega sporting events, such as the 2014 CWGs in Glasgow. In this paper we explore some of the key ways in which the CWGs are being seen as a way of deconstructing and reconstructing in more 'acceptable ways', working-class lives in some of the most disadvantaged areas of the city. We suggest that a critical and progressive understanding of these seemingly discrete processes is needed.

We see this paper as a position piece whereby we forward a reading of the CWGs as a form of urban restructuring born out of neo-liberalism, involving two key components of 
governance: the market-led strategies of the state, and the expansion of individual participation and citizenship via consumption. This is a key way of directing the issues away from structural processes and issues, such as deindustrialisation and class, towards individualisation. We begin by foregrounding the classed relations of regeneration, expressed through the 'problem' places 'problem' people narrative. In the section which follows we demonstrate how regeneration involves the promotion of 'consumer citizenship' as a moralising practice which seeks to create individualised 'responsible' consumer citizens. We supplement this Foucauldian understanding with literature in gentrification which focuses on the distinctly class based nature of the regeneration project. In the final part of this paper we demonstrate how this reading can by applied to the 2014 CWGs. It is a position piece in that it tentatively sets up this reading as a precursor to empirical research on the Games in 2014 and also because we hope that it sparks debates on these issues both within and beyond the academic community.

\section{THE CLASSED RELATIONS OF URBAN REGENERATION}

That urban regeneration, and urban policy more generally, are ambiguous and contested notions has been well documented (see Allen 2008; Cochrane 2007). While there is also some recognition, albeit variably partial and uneven, that urban regeneration relates to issues and questions of class, there is less understanding that it is a classed practice. By this we mean that urban regeneration policy - in its widest sense - is crucially concerned with the regulation, management, control and social reproduction of particular populations; populations which may be considered to be problematic, flawed and disorderly in different and multiple ways. The misunderstanding of the classed nature of regeneration in this respect is both surprising and to be expected. It is surprising in that if we understand that the history of housing in this country is crucially tied-up with questions of class, housing is a particularly significant dimension of urban regeneration. More specifically, of course, the history of social housing in the UK is associated with the working class, materially, 
demographically, spatially, culturally, narratively and politically (Hanley 2008; Ravetz 2001). Social housing is the product of conflicts rooted in class relations and as with many other areas of the British welfare state, reflects cross generational class struggles. From the late nineteenth and early twentieth centuries, to campaigns around rents, against housing stock transfer and the poll tax in the late twentieth century and early 2000s, social movements rooted in working-class communities have been vital in both securing and defending state forms of housing provision (see Annetts et al 2009).

This oversight in much of the housing and urban literatures today is also to be expected, reflecting as it does both a wider neglect of class and an unwillingness to understand that collective mobilisations of class are still a feature of contemporary UK society, albeit unevenly and sporadically. Class action, however, is not simply bottom up. Attacks on public sector housing, from the Conservatives under Thatcher in the 1980s through to New Labour in the late 1990s and 2000s, continue today under the Conservative-Liberal Democrat UK Coalition government (see for example, Forrest and Murie 1988; Hodkinson 2010; Watt 2008). Current market-led approaches to housing and regeneration are predicated on the idea that many of the social problems and ills that characterise urban Britain today are to be found primarily in working-class districts and council estates. The 'problem' council estate is itself a recurring motif of urban regeneration and housing policy since the 1930s (Damer 1989). Today this emerges in a number of different contexts where narratives around the 'crisis of welfare' are mobilised (Mooney and Neal 2010). These negative discourses stigmatise and misrecognise working-class communities, and are echoed across government reports, academic studies, popular literature and other media.

These issues have been explored within recent class literature (Haylett 2001, 2003; Johnstone and Mooney 2007; Mooney 2008; Watt 2008). They focus on the way that cultural representations of class serve to 'other' particular sections of the working class. In doing so, 
these processes produce and reproduce a potent symbolic distinction between the middle and 'respectable' working class, and a working class who are deemed to be problematic in social, economic, cultural and spatial terms (McDowell 2006; Raisborough and Adams 2008; Reay 2007; Skeggs 1997, 2004). The spatial aspect of this is important, as McDowell (2006) highlights, because there is a recurring spatial fixing of class and space whereby particular classes come to be associated with particular places. Skeggs (2004: 15) also observes that 'geographic referencing is one the contemporary shorthand ways of speaking class'. In the contemporary UK, council housing estates (while acknowledging the diversity and heterogeneity of these) are generally imagined as 'other' spaces, as landscapes of poverty, worklessness, welfarism and disorder. As Haylett $(2001,2003)$ among others has demonstrated, policy approaches to such locales are increasingly couched in a language and narratives which focus upon the apparent cultural shortcomings of a backward, parochial and uncompetitive working class. More recently one means by which this is being mobilised is in terms of flawed consumption patterns which reflect abnormal lifestyles. One of the most potent ways in which such narratives are being carried is through a renewed fascination with disadvantaged working-class lifestyles. This is not only a matter of misrecognition and 'othering' at a symbolic level - it gives rise to particular forms of policy making which targets such populations for particular kinds of intervention and regulation (Lister, 2004; Wacquant 2008).

Applied to a policy context this elucidates how class is replaced with a set of narratives around moralised differences, boundaries and binaries. Here a set of euphemisms are deployed: 'included', 'excluded', consumer and the non - or flawed consumer, 'hard-working' versus 'welfare dependents' underpinned by a series of moral geographies constructed and mobilised around class. A concern to make sense of the classed landscapes of urban Britain have been replaced, however, with a focus on privatised and middle-class forms of consumption around housing in particular (see Allen 2008; Flint, In Press; McKee, In Press; 
Paton 2010). The housing consumption practices of the middle classes (a social group often homogenised in ways that are highly problematic) come to be accepted and taken as the 'norm' against which working-class consumption practices are viewed as flawed. It is around such narratives that urban regeneration comes to be advanced as a particular form of classed regulation, working to transform places of decline, of failed lives and communities into more productive spaces which emulate middle-class consumption practices. The sections that follow consider how this narrative has been articulated via notions of citizenship in relation to housing tenure and the use of gentrification as a regeneration strategy, before considering how this can be applied to a study of Glasgow CWGs 2014.

\section{CITIZENSHIP AND THE ‘FLAWED CONSUMER’ IN THE URBAN CONTEXT}

The 'problem' people and 'problem' places narrative reflects a largely naturalistic and individualistic explanation about the causes and solutions to inequality. It presumes a deficiency in the way in which 'the poor' conduct themselves (in terms of their attitudes to work, family relationships etc), with the necessary solution involving the targeting of particular 'problem groups' in order to build-up their capacities and skills so that they can 'enterprise' their own lives and reduce their welfare 'dependency'. Citizenship is thereby conditional on 'responsible' conduct as understood through acts of consumption. As Bauman (1998) asserts consumption is now the defining feature of our post-modern society. Individual subjectivities are shaped and mobilised through our capacity and desire to consume, with 'freedom' and the ability to choose representing key technologies of governance.

For Rose (2000), this reconfiguration of state-citizen relations represents a new 'politics of conduct' that seeks to construct individuals as 'empowered' citizens who can take responsibility for their own life outcomes, including their ability to purchase and consume goods and services (see also Flint 2003). Citizenship in the age of neoliberalism has now 
become inextricably linked to consumption in a civilising project aimed at reconciling behaviour with moral discourses of responsible and responsibilised behaviour. Individual welfare and success now hinges upon the ability of consumer-citizens to 'actively' participate in the labour market and enterprise their own lives, as opposed to being 'passive' and 'dependent' on the state (Cochrane and Etherington 2007). This governmental objective of simultaneously empowering citizens on the one hand, and making them responsible for their own life outcomes on the other, was a defining feature of the previous New Labour UK government (Clarke et al 2007), and is a policy and political discourse that has remained under the new Conservative-Liberal Democrat UK coalition regime. Indeed, this political rhetoric of self-help and individualism has a long history, and can be traced back to the Thatcherite project of the 1980s, and its commitment to 'rolling back the state' through policies such as the Right to Buy (council housing) and Community Care.

However, it is not simply access to consumption that is important, but the expectation that individuals will direct acts of consumption themselves through self-governing acts requiring education, effort and above all else 'active' agency (Rose 2000). As Bauman (1998) and others have underlined, this signifies the increasingly conditional nature of citizenship, and the way in which those individuals who are unable to undertake 'normalised' acts of consumption are stigmatised as 'flawed consumers'. The ability to consume has therefore come to represent an important marker of distinction between the majority, who are able to purchase goods and services on the market, and the minority who cannot, and are thereby dependent on state intervention and support. This not only legitimises exclusion, but also creates dividing practices which identify and target particular groups of people and locales for attention - unifying or homogenising them in terms of their inability or unwillingness to conduct themselves as active, responsible citizens. An illustrative example of this is policy and political discourses in the UK which intrinsically link homeownership with desirable and 'responsible' self-conduct. A key feature of UK housing policy over the last 30 years has 
been the state's desire to increase homeownership whilst, at the same time, reducing public sector provision. Homeownership is increasingly framed as the most 'natural' tenure of choice, with social housing problematised as the 'tenure of last resort' (Gurney 1999; McIntyre and McKee 2008, 2009; McKee, In Press). Housing consumption has therefore come to represent an important point of departure between 'successful' and 'flawed' consumers: the majority who can undertake socially sanctioned acts of consumption (i.e. owner-occupation), and the minority who cannot and are dependent on public provision (i.e. social renters) (Flint 2003). This division serves to mobilise cultural stereotypes about homeowners and social renters for, as Flint (2004) among others argues, it is not just housing that has a defined social image, but ultimately the people who live within it. Overall, these policy shifts highlight the way in which citizenship has been re-imagined under neoliberalism, and public policy increasingly marketised and reinterpreted along economic lines. No longer is the state expected to plan for and solve all of society's problems; rather individuals are expected to be active in enterprising their own lives (Rose 2000).

Nonetheless, a major limitation of the consumer-citizen literature is a lack of explicit class analysis (Kerr 1999). This is largely due to the Foucauldian origins of this mode of analysis, which focuses on subject formation and governing beyond the state, thus ignoring the continued persistence of class as both a relationship of production and a basis of inequality (Clarke et al 2007). The study of gentrification looks at similar neighbourhood based processes through the geographic dynamics of capital accumulation and spatial fixes of accumulation (Harvey 1982; Smith 1996) and supporting consumption practices (Caulfield 1994; Ley 1986, 1996), yet in a way that is intrinsically classed. Drawing insights from both schools of thought thereby offers a potentially useful conceptual lens. 


\section{REGENERATION AS GENTRIFICATION}

While Foucauldian approaches are often applied to studies of homeownership in relation to consumption and citizenship, gentrification - which describes the increase in middle-class homeownership in predominately working-class neighbourhoods - has traditionally been underpinned by Marxist (Harvey 1982; Smith 1996, 2002) and Liberal Humanist accounts (Caulfield 1994; Ley 1986, 1996). These orthodox definitions of gentrification offer discrete economic and cultural explanations of this class transformation of neighbourhoods. Either way, gentrification is fundamentally a process of class restructuring which is spatially articulated at the neighbourhood level. Nowadays, rather than simply being driven by economic or cultural factors, gentrification is explicitly recognised as being increasingly driven by the state as part of urban regeneration, evident in most towns and cities in the UK and beyond (Atkinson and Bridge 2005; Hackworth 2002; Slater 2006). This is described as 'third model' gentrification, which is entrenched within urban policy both locally and globally to the degree that Lees and Ley (2008: 2379) comment: 'in cities and countries around the world, gentrification has become an active part of public policy based on a "gentrification blueprint" that is contextually adjusted'. The state recognises the fiscal benefits of attracting people and capital to areas and uses gentrification processes to help deliver economic imperatives. This is evident in UK urban policies such as the Urban Task Force report, Towards an Urban Renaissance (1999), the policy goal of socially mixing communities (SEU 1998) and the Scottish Executive's People and Place (Scottish Executive 2006) policy statement which encourage those who left the city, predominantly the middle-class, to move back. Often this is to areas that have deemed to have 'declined' or be 'blighted' by deindustrialisation such as former neighbourhoods built upon industry (especially along abandoned or derelict waterfronts), and inner-urban or peripheral post-war housing estates. While focusing on the same issues as Foucauldian understanding of tenure change and homeownership, this perspective highlights more clearly capitalist, profit-driven processes that are occurring. 
This state-led form of gentrification has been described by Hackworth (2002) as the creation of space for the more affluent user. This broader definition advances orthodox explanations, recognising how gentrification is used to turn sites once given to production and/or deemed unproductive into sites of consumption, like retail and conference centres and mega sporting events like the CWGs. Gentrification is thought to help improve the image of cities and neighbourhoods to make it more attractive to potential investors and tourists. However Uitermark et al (2007) offer a more sophisticated insight into the state's use of gentrification. Their recent research, based on policy-led gentrification to create social mix in Rotterdam, argues gentrification is used as a strategy to govern. They point out that policy-led gentrification does not have an immediate profit nor does it necessarily lead to direct displacement. It has an additional objective - not only to displace but to 'civilise' unruly populations in 'declined' areas. Gentrification is used by local states to reshape the relationship between state and citizens via participation. In this context, gentrification is used not to displace but rather to manage working-class populations (Uitermark et al 2007).

The current definition of gentrification as the creation of space for the progressively more affluent user (Hackworth 2002) can be usefully revised to suggest that gentrification policies fulfil financial and cultural imperatives by seeking to cultivate aspiration and realign traditional working-class identities to be more congruent with post-industrial neoliberalism. This is principally achieved through promoting consumption and participation and thus class culture is a key point of intervention. This has become intrinsic to urban policies in general. This form of regeneration often does little to improve people's labour market conditions or material situations. That is, the productive regeneration interventions which aim to get people working often lack the secure employment needed to ensure this. Nonetheless people who are targeted by regeneration are still expected to become better consumercitizens. In this way, gentrification processes simultaneously exclude and include working- 
class residents. The paradox of policy-led gentrification is that it invites people to participate in the processes it promotes, including retail sites, private housing and so on. However, this involves private consumption and it does not provide the means to achieve this. Thereby working-class residents are invited to participate but face an economic barrier in doing so, and are then censured for not becoming consumer-citizens.

What both Foucauldian literature on housing and literature on gentrification reveal is that regeneration strategies are a form of urban restructuring borne out of neo-liberalism, involving two key components of governance: the marketisation and growth focused strategy of the state, and the expansion of individual participation and citizenship via consumption. This is the formula for regeneration strategies, comprising both economic imperative, rolling back of social welfare and promotion of investment and revenue generation. It also involves social intervention which vilifies the practices and behaviours of working-class communities which are based on social welfare practices. This is a key way of directing the issues away from structural processes such as deindustrialisation towards individualisation. We argue here that mega-sporting events should be understood within this context since it forms an increasingly important branch of urban regeneration.

\section{GLASGOW CWGs 2014: A FESTIVAL OF CONSUMPTION?}

The East End was a key locale during Glasgow's 'second city' era in the late nineteenth and early twentieth centuries. It accommodated many of the industries which fuelled the expansion of the British Empire, upon which Glasgow's economic growth was largely dependent. The decline of the Empire together with the ravages of successive decades of deindustrialisation, disinvestment and economic destruction left the area with high levels of unemployment, poverty and other social ills. As such, during the 1970s the East End of Glasgow was the target for Scotland's version of the English Inner Cities policy. The Glasgow Eastern Area Renewal (GEAR) project was a large-scale, comprehensive urban 
renewal programme which promised economic regeneration, employment and environmental improvements; however, in the context of deepening economic crisis, and the onslaught of Thatcherism and New Right policies, there were precious few signs of renewal and regeneration (Damer 1990; Donnison and Middleton 1987; Lever and Moore 1986; Pacione 1995). As Damer (1990: 13) comments:

If one analyses the academic reports on the much vaunted GEAR, whatever its achievements, making inroads into local unemployment is not one of them. Precisely fourteen long-term unemployed East Enders got jobs as 'small entrepreneurs' out of GEAR, generating another sixteen jobs.

Whilst attempts to tackle concentrated deprivation in the East End are to be welcomed, history highlights that such localised, market-led regeneration projects are unlikely to offer the solution. Despite decades of targeted policy initiatives the East End of Glasgow is still home to Scotland's, and the UK's, most deprived communities; it remains a stubborn 'final frontier' (Gray and Mooney 2011) in Glasgow's quest to become a vibrant post-industrial city (Garcia 2004; Gomez 1998; Mooney 2004). In this new phase of urban renaissance, Glasgow East is viewed as holding back not only the continuing prosperity of Glasgow today, but also that of the Glasgow and the Scotland of the future. In this respect, areas such as the East End become important signifiers: an eponym for backwardness and decay. The idea of Glasgow as a dual city (Castells 1994: 30), a new city that is prospering and 'forward looking' and an 'old' Glasgow of decline, dereliction and deprivation has been extensively criticised (Mooney and Danson 1997; Young 2007: 23-7). However, the idea of Glasgow as a tale of two cities, or 'two-tier city', continues to influence both political rhetoric and policy intervention. The symbolic importance to this narrative is that it conveys the argument that Glasgow East needs to be either 'connected' or 'reconnected' to the city of economic growth and prosperity, not least also to the city of a vibrant and rising property market. 
It is against this backdrop that our understanding of contemporary developments, such as the CWGs needs to be situated; it is simply the latest in a long-line of area-based, marketled urban renewal projects designed to revitalise, modernise and renew the East End of Glasgow.

Recent developments in Glasgow, in terms of the 2014 CWGs, provide an interesting case study in which to explore and tease out some of these policy tensions and contradictions. On November 9 2007, the Commonwealth Games Federation chose Glasgow as the host city for the 2014 Games. Then Deputy First Minister in the Scottish National Party minority Scottish Government, Nicola Sturgeon, claimed that the event would:

.... bring a host of benefits to Glasgow and Scotland, including everything from regeneration, job creation, inward investment and just a huge pride in being Scottish. (Source: BBC News November 9, 2007)

Sturgeon was by no means alone in arguing that the CWGs would 'transform' the East End of Glasgow, where new sporting facilities and an Athlete's Village are to be located. The focus on this area of Glasgow is significant, because as previously mentioned, it represents perhaps the last major part of the city to be targeted for private sector property development via urban renewal programmes (Damer 1990; Gray and Mooney 2011). The role of sporting events in relation to urban economies has been recognised for some time in the context of deindustrialisation and increasing service sector economies. Urban politics increasingly focus on growth via partnership with private business to offset cuts in local government budgets. Sporting events have a major role in the neoliberal urban governance seen in the augmentation of partnership and coalitions for growth (see image 1). Cochrane, Peck and Tickell (1996) have highlighted the role of public private partnerships were central to 
Manchester's bid for the 2000 Olympics. The value of mega sporting events from the government's perspective has to be articulated in long term benefits rather than short term fixes in order to justify the public expenditure. As Matheson (2010:10) emphasises, 'investment longevity must be proven with the creation of legacies'. The language of legacy belongs to the family of 'effects' and 'outcomes' commonplace in policy discourse on regeneration (Matheson 2010; Gold and Gold 2008). It is underpinned by the same 'trickledown' philosophy that characterises regeneration strategies: that social and economic benefits will filter down to communities deemed to be lacking value in both. Sporting events are therefore thought to create virtuous circles. The notion that there will be a 'legacy' encourages community stakeholders to support the event, for it can provide a return on investment and justification for public expenditure (Matheson 2010).

[INSERT IMAGE $1 \mathrm{HERE]}$

The CWGs together with other plans for the East End are part of a larger waterfront regeneration strategy along the planned £5.6 billion, 13-mile Clyde River corridor development. After several decades of general political and policy making neglect and failure, the East End and its population are now deemed to have an important role in Glasgow's economic prosperity:

The economic position of the East End remains poor... A complex set of factors combine to limit progress. The area continues to have high levels and concentrations of poverty and low levels of economic activity, and its residents suffer from poor health, significantly affecting their economic potential. The area still houses some of the poorest communities in the UK and contains high levels of derelict and contaminated land currently unusable for economic activity. (East End Partnership Limited undated, p. 5) 
Alongside land for speculative property development, the East End also offers a large reserve of labour power. The transformation of this area, however, also means a concerted policy and political effort to transform the local populous. Glasgow CWGs 2014 marks a key plank in this strategy, challenging the 'welfarism' that is deemed to be rife in this locality, and offering other legitimated forms of consumption.

But most importantly, all of this activity which will see billions of pounds being spent, will bring genuine once-in-a-lifetime opportunities to the people of Bridgeton, Dalmarnock, Rutherglen and Shawfield, with new jobs and new homes being the key priorities. (Clydegateway undated)

This is above all a strategy that is premised upon particular understandings of the disadvantaged working-class of Glasgow: that they are 'work-shy', 'welfare dependent' and 'marginalised' from the rest of Glasgow and/or Scottish society more broadly. What this does is put the emphasis onto individuals taking responsibility for their own welfare, instead of relying on state support. Not only is this highly questionable in a climate of public sector cuts and high unemployment, such thinking neglects the structural inequalities facing East Enders in their attempts to become 'consumer-citizens'. Despite decades of targeted interventions, the Shettleston Parliamentary Ward, where much of the CWGs activity will be located, continues to experience high levels of deprivation and inequality. As Table 1 indicates, across a range of socio and economic indicators neighbourhoods within Glasgow East continue to have an unenviable reputation as sites of poverty, ill-health, urban-decay and welfare dependency.

[Insert Table 1 -_at end of paper]

The 'legacy' of the CWGs, however, promises to transform these 'problem' neighbourhoods; in this narrative 'reconnecting' them to the economic benefits and prosperity experienced by 
other Glaswegians. Projected economic impacts suggest £26 million net economic benefits for Glasgow and £81 million at a Scottish level. Legacy plans for the Games are wideranging and relate to outcomes for health, education, employment and sustainability:

An Active Scotland, a Connected Scotland, A Sustainable Scotland and a Flourishing Scotland represent our ambitions for a lasting and positive legacy. [The CWGs] are about making faster progress towards a healthier nation; developing healthy communities; and a strong and flourishing economy (Scottish Government 2009: 6)

At the city level, the regeneration of the East End of Glasgow is central to delivering upon these objectives. Although the CWGs will be located throughout and even beyond the city's boundaries, a large cluster of venues, including the Athlete's Village, the Velodrome and the National Indoor Sporting Arena, will be located in the Parkhead and Dalmarnock wards in the East End (please see map and images 2 and 3 below), thereby offering the potential for the aforementioned event-led regeneration.

[INSERT MAP 1 AND IMAGES 2 AND 3]

Co-ordinating this regeneration effort is the Clyde Gateway Urban Regeneration Company, who promise the creation of a 'dynamic and sought after city location' close to the centre of Glasgow (Clyde Gateway, undated: 4), with improved transport connectivity to the rest of the city and beyond through the new M74 motorway extension, the East End regeneration (road) route, and the refurbishment of Dalmarnock train station. The aim here is to expand the city centre beyond the current eastern boundary of the Merchant City, and to reimagine the East End as a place that both Glaswegians and visitors to the city alike will want to visit, for shopping, entertainment and leisure. In this context the East End becomes a place reconnected with economic growth elsewhere in the city, West Central Scotland and beyond. 
Sports-led urban regeneration, for city politicians and other 'boosterists', enables not only economic growth and employment of sharply contrasting quality and durability, but also opportunities for land speculation - that is, private sector opportunity and reward in the name of public interest and gain.

[INSERT IMAGE 4]

As well as recreating the East End as a space for consumption, the creation of a 'sustainable, vibrant new neighbourhood' is also central to legacy commitments (Scottish Government 2009: 33). Post-Games, the Athlete's Village will be converted into a new mixed-tenure residential community with over 10,000 new homes (Clyde Gateway, undated), thereby transforming the area's housing market, which is currently dominated by social housing (see image 4). The use of tenure-mix as regeneration strategy is well established in Glasgow (Mclntyre and McKee 2008, 2009). It reflects the 'problematisation' of mono-tenure social housing estates within currently policy debates, and the promotion of homeownership as a solution to reconnect disadvantaged communities back into mainstream society. Although planned projections for social housing are higher for 2014 than in previous CWGs (Matheson 2010), not only is the new residential development likely to be unaffordable for low-income East Enders, who have incomes well below the Scottish average, but redevelopment has already resulted in the displacement of local families, and disputes over compensation (Porter et al 2009). Therefore whilst the CWGs might aspire to 'create real and permanent economic progress' (GCC 2009: 5), its legacy will not be felt equally by all of Glasgow's citizens nor by all of those residents remaining in the East End; an argument advanced by Damer (1990) in relation to previous regeneration initiatives designed to transform Glasgow's image. This demonstrates the problem with using the language of 'legacy'; it is nebulous and opaque, and its language obfuscates the real agenda of urban regeneration. The international evidence that exists on the legacy of sporting events around the world highlights that there is some limited success in relation to tourism and city 
branding. However, for the most part, evidence is not very tangible, particularly in relation to the primary stated social benefits pertaining to sport and health:

...existing evidence suggests that the presumed "trickle-down effects" of general increases in sports participation and a general improvement of fitness in health are unlikely direct outcomes of a successful Olympic Games bid. (Coalter 2004: 107)

While 'legacy' is used to denote the focus on long-term and far-reaching effects it is also conveniently vague and immeasurable in a tangible sense. There is also an inherent problem in the policy position of naming the outcome and the tools for measuring the outcome, for example the development of evidence based performance indicators of economic impacts which aim to measure the effects (Gratton et al 2005). Further, and related to this, conceiving mega sporting events like the CWGs in terms of legacy forecloses the idea that there will be negative impacts, contestation or resistance at the local level. Legacy suggests that only positive impacts lasting impacts will be generated (Cashman 2003). Indeed some of the impacts are explicitly deleterious. Local East Enders are becoming increasingly critical of the 'legacy' the CWGs will have (Glasgow Games Monitor 2014 2011). At the more extreme end of the scale, mega sporting events have been found to lead to displacement of situated communities who are predominately poor and marginalised groups. As Porter (2009) points out displacement is the defining feature of mega sporting events and Glasgow CWGs are no different. Margaret Jaconelli was evicted from her home in Dalmarnock on the $24^{\text {th }}$ March 2011 following a lengthy fight against the compulsory purchase order on her property in a high profile case. She was offered $£ 30,000$ for her home which, after lengthy legal negotiations, was increased to $£ 90,000$ despite the fact that the average house price in Glasgow is $£ 140,000$ (Glasgow Games Monitor 2014 2011). A report by the Centre on Housing Rights and Evictions (COHRE 2007:11) suggests that the Olympic Games and other events such as CWGs are 'often catalysts for redevelopment entailing 
massive displacements and reductions in low cost and social housing stock, all of which result in a significant decrease in housing affordability'. In addition to this the Accord Resource Centre for adults with learning disabilities in the East End faces closure and demolition to make way for a Games related road. The centre offers care management and assessment, specialist health services, day services, respite, supported living and supported employment schemes for over 500 people with learning disabilities. A $£ 250,000$ replacement centre had been planned by Glasgow City Council. However this now seems unlikely to be delivered. Glasgow Games Monitor 2014 (2011) report that the Vice-Convener of the Planning Committee said that such assurance were made in different economic climate and the policy direction agreed by the Council in respect of the modernisation of learning difficulty services. This highlights the inherent problem of using market led approaches to regenerate. Glasgow Games Monitor 2014 (2011 no page number), a diverse grassroots group of people raising awareness about the about the events, make their cynicism plain:

[M]ega-events like the Commonwealth Games are more about land-grabs, than helping the local community; more about property speculation than social housing; more about the image of the city than its reality.

Importantly this foregrounds the need for longitudinal research which assesses the real long term impact of sporting events on local communities (Matheson 2010).

It is clear that sporting events fit with the regeneration formula highlighted where the goal is to fulfil financial and cultural imperatives by seeking to cultivate aspiration and realign traditional working-class identities to be more congruent with post-industrial neoliberalism (Paton 2009; 2010). Communities targeted by mega sporting events, like the East End of Glasgow, are encouraged to participate in these regeneration processes. As Matheson (2010) highlights in her preliminary pre-event research in Glasgow, continued community support for the CWGs is vital to its success, which means that it would be counterintuitive to allow space for criticism or dissenting voices. However, ironically, pre-event assessments of 
legacies are an essential part of legacy panning, helping to identify and prevent potential problems and risks. It seems within the current model there is little room of alternative views, which denies the chance of shaping the CWGs in the East End community's own vision.

\section{CONCLUSION: A POST-WELFARIST EAST END?}

Is there anything new in the developments we have highlighted here? Are 1980s and 1990s urban regeneration programmes being rehashed and rebadged with little that is substantially different or innovative? Certainly there are all too many visible indicators of a strategy that is underpinned by the now widely discredited trickle-down approach, allowing the private sector to prosper in the hope of some future economic growth and prosperity, couched in a language that speaks of 'legacy', 'sustainability' and long term 'benefits for all'.

Alongside this, however, there are some significant changes from the past. During the $1980 \mathrm{~s}$ and 1990s, areas such as Glasgow's East End, large public sector housing estates across Scotland and elsewhere in the UK were, for the most part, generally neglected and abandoned spaces in terms of policy interventions (Damer 1990; Mooney and Danson 1997). Economic growth and prosperity was something that happened to places and to people located elsewhere. In the context of the late 1990s and 2000s, however, there is renewed political and policy making concern to re-connect such 'marginal' localities to national economies (here understood both in Scottish and UK senses). The other significant shift comes in the form of the 'social' element of such a strategy. Returning to Cochrane's (2007) understanding of urban regeneration as an 'active social policy', it is difficult to disentangle the economic from the social, cultural and political aspects of such 'renewal'. While there is much policy rhetoric around reconnecting the East End (and similar locales elsewhere) with mainstream economic activity, there is something else, just as fundamental, at play here. The CWGs 2014, and related policies, have as their core objective the 'normalisation' of the East End. 'Normalisation' here means 'mainstream' economic 
activity/participation against a culture of 'welfarism' and illicit forms of work; it also means legitimated forms of consumption - against the flawed consumption of a welfare dependent population that is viewed as not only over-reliant on social housing, but on public services more generally. The problem with this is the lack of evidence for increased in labour participation through quality and secure job opportunities brought by regeneration efforts. Indeed, as preliminary evidence indicates, the legacy of the Games maybe a negative one with the closure of essential welfare support services - the gap left by the lack of state provision - such as the Accord Centre. If the plans or 'legacy' are unsuccessful yet again 'problem' people and 'problem' place are blamed for the failed effort.

The concern to promote tenure-mix and the drive to encourage and enable private sector penetration of local amenities and services is also about transforming local aspirations. Concentrated poverty can be challenged, in this narrative, through the introduction of diverse housing tenures, especially through owner occupation. Likewise employability can be enhanced through training and a range of increasingly harsh anti-welfare measures, which will operate to ensure that any remaining workless recalcitrants, especially those on disability benefits, will be forced to take-up whatever work is available. Enabling legitimatised and morally correct forms of consumption (for poor working-class people that is) promotes aspirational changes and a transformed sense of self amidst a new urban landscape of self help and entrepreneurialism. Pessimism, parochialism, living for today, seen as the hallmarks of a culture of poverty (as opposed to structural poverty) are thereby challenged. The East End will become a 'normal' place, home to the ideal citizen-subjects of today: 'hard-working families' and consumers. Workfare, employability, privatisation, urban regeneration are entangled here in a heady neoliberal-led assault on the 'welfarism' that is seen as a major cause of social problems in the East End, the driver of the 'broken society'. Yet alongside the rhetoric of renewal and regeneration there is also slum clearance, decantment and population displacement, all policies with a long and very troubled history in 
the context of Glasgow. As Porter et al have highlighted (2009) displacement is a defining feature of the mega-event whereby those on the receiving end of such top down policy interventions become even further marginalised. While displacement in Glasgow ahead of the 2014 CWGs is not on the scale of that which took place in Delhi ahead of the 2010 CWG (Baviskar 2006), it nonetheless has real, personal consequences which are devastating for those affected.

As Harvey (2005) has reminded us, neoliberalism is above all a class project - for the ruling classes that is. The concerted effort to regenerate, regulate and normalise the populations of areas such as Glasgow's East End represents that class project in action at the frontline, so to speak. Disadvantaged working-class lives are deemed as problematic, anti-modern and out of step with the revitalised and aspirational world of the new Glasgow, the new Scotland and the new UK. This is advanced against the images of long term decay and dereliction the product of decades of failed state interventions: dependency versus aspiration, decline versus dynamism, the old Glasgow versus the new Glasgow. Yet the attempted retrenchment of social welfare in this world is faced with a diverse set of antagonisms and contradictions. In the context of deepening economic crisis, rising unemployment and reductions in public services and provision, the idea that the East End will be transformed in ways that meet the needs of the local population is at best naive but which also draws attention away from more fundamental structural inequalities. With voices already being raised that the 2014 Games and other related urban and housing strategies are marginalising local residents, the period running up to the Games promises to bring these issues into even sharper focus.

\section{References}

Allen, C. (2008) Housing Market Renewal and Social Class. London: Routledge. 
Annetts, J., Law, A., McNeish, W. and Mooney, G. (2009) Understanding Social Welfare Movements. Bristol: Policy Press.

Atkinson, R. and Bridge, G. (eds) (2005) Gentrification in a Global Context: the new urban colonialism. London: Routledge.

Bauder, H. (2002) Neighbourhood Effects and Cultural Exclusion. Urban Studies 39 (1): 8993.

Bauman, Z. (1998) Work, Consumerism and the New Poor. Buckingham: Open University Press.

Baviskar, A. (2006) Demolishing Delhi: World Class City in the Making. Mute, available at: http://www.metamute.org/en/Demolishing-Delhi

BBC News (2007) 'Fruitmarket starts 2014 party', BBC News Online, available at (accessed October 25 2010): http://news.bbc.co.uk/1/hi/scotland/glasgow and west/7086680.stm Cashman, R. (2003) What is ‘Olympic legacy’?, in: M. Moragas, C. Kennett \& N. Puig (eds) The Legacy of the Olympic Games, 1984-2000 (pp 31-42). Lausanne: IOC.

Castells, M. (1994) European Cities, the Informational Society, and the Global Economy. New Left Review 204 (March-April): 19-35.

Caulfield, J. (1994) City Form and Everyday Life: Toronto's gentrification and critical social practice. Toronto: University of Toronto Press.

COHRE (Centre on Housing Rights and Evictions) (2007) Fair Play for Housing Rights: Mega-Events, Olympic Games and Housing Rights, available at: http://www.cohre.org/mega$\underline{\text { events-report }}$

Christopherson, S. (1994) 'Fortress city: privatised spaces, consumer citizenship' in A. Amin (ed) Post-Fordism: a Reader (pp 409-427). Oxford: Blackwell.

Clarke, J; Newman, J; Smith, N; Vidler, E. and Westmarland, L. (2007) Creating CitizenConsumers: changing publics and changing public services. London: Sage.

Clyde Gateway (undated) A Dynamic City Location: Clyde Gateway City Plan [online], available at: http://www.clydegateway.com/downloads/cg business plan.doc 
Coalter, F. (2004) Stuck in the blocks? A sustainable sporting legacy. In A. Vigor, M. Mean and C. Tims (eds) After the Gold Rush: A Sustainable Olympics for London (pp 93-108). London: IIPR and Demos.

Cochrane, A. (2007) Understanding Urban Policy, Oxford: Blackwell.

Cochrane A; Peck J; Tickell A. (1996) Manchester plays games: the local politics of globalization. Urban Studies 33: 1317-1334.

Cochrane, A. and Etherington, D. (2007) Managing Local Labour Markets and Making up New Spaces of Welfare. Environment and Planning A 39(12): 2958-2974.

Damer, S. (1989) From Moorepark to 'Wine Alley’. Edinburgh University Press: Edinburgh.

Damer (1990) Glasgow: going for a song. Edinburgh University Press: Edinburgh.

Donnison, D. and Middleton, A. (eds) (1987) Regenerating the Inner City, London:

Routledge and Kegan Paul.

East End Partnership Limited (Undated) Strategic Plan: East End Partnership 2002-2007, Glasgow: East End Partnership Limited.

Flint, J. (2003) Housing and Ethopolitics: constructing identities of active consumption and responsible community. Economy and Society 32(3): 611-629.

Flint, J. (2004) Reconfiguring agency and responsibility in the governance of social housing in Scotland. Urban Studies 41(1): 151-172.

Flint, J. (In Press) Housing Studies, Social Class and Being Towards Dwelling. Housing Theory and Society.

Forrest, R. and Murie, A. (1988) Selling the Welfare State: the privatisation of public housing. London: Routledge.

Garcia, B. (2004) Urban regeneration, arts programming and major events: Glasgow 1990, Sydney 2000 and Barcelona 2004. International Journal of Cultural Policy 10 (1): 103-116. Glasgow City Council (2009) A Games Legacy for Glasgow, Glasgow: GCC. Glasgow Games Monitor (2011) East End Eye [online] available at http://gamesmonitor2014.wordpress.com 
Gold, J. R. and Gold, M. M. (2008) Olympic Cities: Regeneration, City Rebranding and Changing Urban Agendas. Geography Compass 2: 300-318.

Gomez, M. (1998) Reflective images: the case of urban regeneration in Glasgow and Bilbao. International Journal of Urban and Regional Research 22(1): 106-121.

Gratton, C., Shibli, S. and Coleman, R. (2005) Sport and economic regeneration in cities. Urban Studies 42 (5/6)985-999.

Gray, N. and Mooney, G. (2011) Glasgow's New Urban Frontier: 'civilising' the population of 'Glasgow East'. City 15 (1): 4-24.

Gurney, C. (1999) Pride and prejudice: discourses of normalisation in public and private accounts of home ownership. Housing Studies 14(2): 163-183.

Hackworth, J. (2002) Post-recession gentrification in New York City. Urban Affairs Review, 37: 815-843.

Hanley, L. (2008) Estates: An Intimate History, London: Granta.

Harvey, D. (1982) The Limits to Capital. Oxford: Blackwell.

Harvey, D. (2005) A Brief History of Neoliberalism. Oxford: Oxford University Press.

Haylett, C. (2001) Illegitimate Subjects? Abject Whites, Neoliberal Modernisation and Middle-Class Multiculturalism. Environment and Planning D: Society and Space 19 (3): 351370.

Haylett, C. (2003) Culture, Class and Urban Policy: Reconsidering Equality. Antipode, 35 (1): $55-73$.

Hodkinson, S. (2010) Housing Regeneration and the Private Finance Initiative in England: unstitching the neoliberal urban straitjacket. Antipode 43 (2): 353-383.

Johnstone, C. and Mooney, G. (2007) 'Problem' People, 'Problem' Spaces? New Labour and Council Estates. In Atkinson, R. and Helms, G. (eds) Securing an Urban Renaissance: Crime, Community and British Urban Policy (pp 125-139). Bristol: Policy Press.

Kerr, D. (1999) Beheading the King and Enthroning the Market: a critique of Foucauldian governmentality. Science and Society 63(2): 173-202. 
Lambert, C. and Boddy, M. (2002) Transforming the City: post-recession gentrification and re-urbanism. CNR Paper 6. Bristol: ESRC Centre for Neighbourhood Research.

Lees L. and Ley, D. (2008) Introduction to a special issue on gentrification and public policy. Urban Studies 45(12): 2379-2384.

Lever, W. and Moore, C. (1986) The City in Transition, Oxford: Clarendon.

Ley, D. (1996) The New Middle Class and the Re-making of the Central City. Oxford: Oxford University Press.

Ley, D. (1986) Alternative explanations for inner-city gentrification: a Canadian assessment. Annals of the Association of American Geographers 76 (4): 521-535.

Lister, R. (2004) Poverty, Cambridge: Polity Press.

Matheson, C.M. (2010) Legacy Planning: regeneration and events. Local Economy 25(1): 10-23.

McDowell, L. (2006) Reconfiguration of Gender and Class Relations: Class Differences, Class Condescension and the Changing Place of Class Relations. Antipode 38 (4): 825-850. Mclntyre, Z. and McKee, K. (2008) Governance and Sustainability in Glasgow: connecting symbolic capital and housing consumption to regeneration. Area 40(4): 481-490.

McIntyre, Z. and McKee, K. (2009) Creating Sustainable Communities through Tenure-mix: the responsibilisation of marginal homeowners in Scotland. Geojournal, Online Early McKee, K. (In Press) Challenging the Norm? The Etho-Politics of Low-Cost Homeownership in Scotland. Urban Studies.

Mooney, G. (2004) Cultural Policy as Urban Transformation? Critical reflections on Glasgow, European City of Culture 1990. Local Economy 19 327-40.

Mooney, G. (2008) Problem Populations, Problem Places. In N.Yeates and J.Newman (eds) Social Justice: Welfare, Crime and Society (pp 97-128). Bristol: Policy Press.

Mooney, G. and Danson, M. (1997) Beyond 'Culture City': Glasgow as a 'Dual City'. In N. Jewson and S. MacGregor (eds) Transforming Cities (pp 73-86). London: Routledge. 
Mooney, G. and Neal, S. (2009/2010) 'Welfare worries': mapping the directions of welfare futures in the contemporary UK. Research, Policy and Planning 27 (3): 141-150.

Pacione. M. (1995) Glasgow: The Socio-Spatial Development of the City, Chichester: John Wiley and Sons.

Paton, K. (2009) 'Probing the symptomatic silences of middle-class settlement: A case study of gentrification processes in Glasgow'. City 13 (4): 432-450.

Paton, K. (2010) Creating the Neoliberal City and Citizen: The use of Gentrification as Urban Policy in Glasgow. In N. Davidson, P. McCafferty and D. Miller (eds) Neoliberal Scotland (pp 203-223). Newcastle: Cambridge Scholars Publishing.

Porter, L; Jaconelli, M; Cheyne, J; Eby, D; and Wagenaar, H. (2009) Planning Displacement: the real legacy of major sporting events Just a person in a wee flat: Being Displaced by the CWGs in Glasgow's East End; Olympian Master planning in London Closing Ceremonies: How Law, Policy and the Winter Olympics are Displacing an Inconveniently Located Low-Income Community in Vancouver; Commentary: Recovering Public Ethos: Critical Analysis for Policy and Planning. Planning Theory \& Practice 10 (3): 395-418.

Ravetz, A. (2001) Council Housing and Culture: the history of social experiment. London: Routledge.

Raisborough, J. and Adams, M. (2008) Mockery and Morality in Popular Cultural Representations of the White, Working Class. Sociological Research Online 13 (6) 2

Reay, D. (2007) Unruly Places: Inner-city Comprehensives, Middle-Class Imaginaries and Working-class Children. Urban Studies 44 (7): 1191-1203.

Rose, N. (2000) Community, Citizenship and the Third Way. American Behavioural Scientist 43: 1395-1411.

Scottish Executive (2006) People and Place: Regeneration Policy Statement. Edinburgh: Scottish Executive.

Scottish Government (2009) On Your Marks: a games legacy for Scotland. Edinburgh: 
Scottish Government.

SEU (Social Exclusion Unit) (1998) Bringing Britain Together - a national strategy for neighbourhood renewal. Cmnd 4045. London: Stationary Office.

Skeggs, B. (1997) Formations of Class and Gender, London: Routledge.

Skeggs, B. (2004) Class, Self, Culture, London: Routledge.

Slater, T. (2006) The eviction of critical perspectives from gentrification research. International Journal of Urban and Regional Research 30(4): 737-757.

Smith, N. (1996) The New Urban Frontier: gentrification and the revanchist city. London: Routledge.

Smith, N. (2002) New globalism, new urbanism: gentrification as a global urban strategy. Antipode 34(3): 434-457.

Uitermark, J., Duyvendak, J.W. and Kleinhans, R. (2007) Gentrification as a governmental strategy: social control and social cohesion in Hoogvliet, Rotterdam. Environment and Planning A 39(1): 125-141.

Urban Task Force Report (1999) Towards and Urban Renaissance: final report of the task force, chaired by Lord Rodgers of Riverside. London: Spon

Wacquant, L. (2008) Urban Outcasts, Cambridge: Polity Press.

Watt, P. (2008) 'Underclass' and 'Ordinary People' discourses: representing/re-presenting council tenants in a housing campaign. Critical Discourse Studies 5 (3): 345-357.

Young, J. (2007) The Vertigo of Late Modernity, London: Sage. 
Table 1: Key Statistics: Shettleston Scottish Parliamentary Constituency

\begin{tabular}{|l|l|l|}
\hline Socio-Economic Indicators & $\begin{array}{l}\text { Shettleston } \\
\text { Constituency }\end{array}$ & Scotland \\
\hline \% Total Population Income Deprived, 2008 & 35 & 15 \\
\hline \% Working Age Population Employment Deprived, 2008 & 25 & 12 \\
\hline $\begin{array}{l}\text { \% Population aged 60+ Claiming Guaranteed Pension } \\
\text { Credit, 2009 }\end{array}$ & 46 & 18 \\
\hline $\begin{array}{l}\text { Hospital Admission for Drug Misuse, per 100,000, } \\
2001-04\end{array}$ & 816.5 & 127.5 \\
\hline $\begin{array}{l}\text { Hospital Admission for Alcohol Misuse, per 100,000, } \\
2001-04\end{array}$ & 2305.3 & 722.7 \\
\hline Average Tariff Position of S4 Students, 2008 & 136 & 180 \\
\hline \% of Households in Social Renting, 2001 & 54 & 29 \\
\hline House Sales, Mean Price (£), 2009 & 105,302 & 159,075 \\
\hline \% People within 0-500 metres of Derelict Site & 82 & 30 \\
\hline
\end{tabular}

Source: Scottish Neighbourhood Statistics 